\title{
High Throughput Analysis of Photocatalytic Water Purification
}

Citation for published version (APA):

Romao, J., Barata, D., Habibovic, P., Mul, G., \& Baltrusaitis, J. (2014). High Throughput Analysis of Photocatalytic Water Purification. Analytical Chemistry, 86(15), 7612-7617.

https://doi.org/10.1021/ac501426f

Document status and date:

Published: 05/08/2014

DOI:

10.1021/ac501426f

Document Version:

Publisher's PDF, also known as Version of record

Document license:

Taverne

Please check the document version of this publication:

- A submitted manuscript is the version of the article upon submission and before peer-review. There can be important differences between the submitted version and the official published version of record.

People interested in the research are advised to contact the author for the final version of the publication, or visit the DOI to the publisher's website.

- The final author version and the galley proof are versions of the publication after peer review.

- The final published version features the final layout of the paper including the volume, issue and page numbers.

Link to publication

\footnotetext{
General rights rights.

- You may freely distribute the URL identifying the publication in the public portal. please follow below link for the End User Agreement:

www.umlib.nl/taverne-license

Take down policy

If you believe that this document breaches copyright please contact us at:

repository@maastrichtuniversity.nl

providing details and we will investigate your claim.
}

Copyright and moral rights for the publications made accessible in the public portal are retained by the authors and/or other copyright owners and it is a condition of accessing publications that users recognise and abide by the legal requirements associated with these

- Users may download and print one copy of any publication from the public portal for the purpose of private study or research.

- You may not further distribute the material or use it for any profit-making activity or commercial gain

If the publication is distributed under the terms of Article $25 \mathrm{fa}$ of the Dutch Copyright Act, indicated by the "Taverne" license above, 


\title{
High Throughput Analysis of Photocatalytic Water Purification
}

\author{
Joana Romão, ${ }^{\dagger}$ David Barata, ${ }^{\dagger}$ Pamela Habibovic, ${ }^{\ddagger}$ Guido Mul,*,† and Jonas Baltrusaitis ${ }^{*}, \dagger, \S$ \\ ${ }^{\dagger}$ Photocatalytic Synthesis Group, MESA+ Institute for Nanotechnology, Faculty of Science and Technology, University of Twente, \\ Meander 229, P.O. Box 217, 7500 AE Enschede, The Netherlands \\ ${ }^{\ddagger}$ Department of Tissue Regeneration, MIRA Institute for Biomedical Technology and Technical Medicine, University of Twente, \\ Drienerlolaan 5, 7522 NB Enschede, The Netherlands
}

\section{Supporting Information}

ABSTRACT: We present a novel high throughput photocatalyst efficiency assessment method based on 96-well microplates and UV-vis spectroscopy. We demonstrate the reproducibility of the method using methyl orange (MO) decomposition and compare kinetic data obtained with those provided in the literature for larger conventional photoreactors. To demonstrate the capabilities of the method, we rapidly screened the effects of salts, potentially present in wastewater, on kinetic rates of MO decomposition and briefly discuss the obtained data on the basis of existing literature.

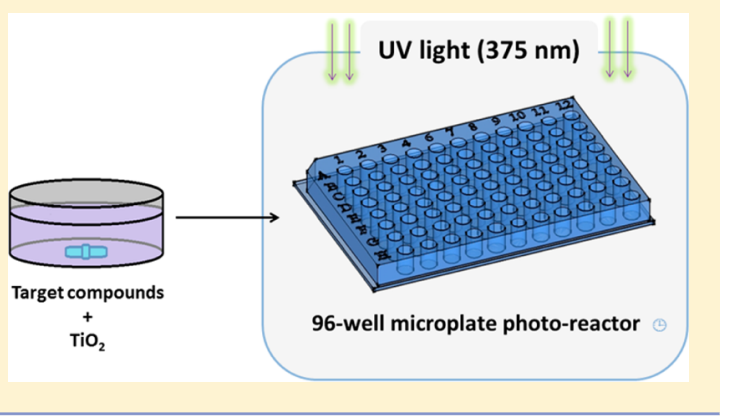

lean water remains one of the major societal concerns. Among the currently available water purification methods, the most common are biological treatment, adsorption on activated carbon, and chemical oxidation, often in combination with membrane and filtration technologies. ${ }^{1,2}$ However, in most of these techniques, polluting organic molecules are not completely destroyed, and the operational costs are high. ${ }^{1-3}$ Heterogeneous photocatalysis opens up new opportunities for water purification since it allows complete mineralization of the organic pollutants into environmentally neutral compounds, such as $\mathrm{CO}_{2}$ and $\mathrm{H}_{2} \mathrm{O}$, with reactions occurring at room temperature at relatively low costs. ${ }^{1,3}$

Photocatalyst activity depends on the inherent ability of semiconductor materials, such as titanium oxide $\left(\mathrm{TiO}_{2}\right)$, tungsten oxide $\left(\mathrm{WO}_{3}\right)$, or zinc oxide $(\mathrm{ZnO})$, to create electron-hole charge carrier pairs when exposed to light. Depending on the type of reactor, photocatalytic systems can be characterized as immobilized or slurry systems, ${ }^{2,3}$ in which light distribution within the reactor and its resulting penetration to reach the catalyst particle surface, as well as mass transfer limitations, need to be carefully considered. ${ }^{3}$ Typical reaction volumes for laboratory scale slurry reactors range from $50 \mathrm{~mL}$ to $1 \mathrm{~L},{ }^{4}$ with $\mathrm{UV} /$ visible illumination supplied to the reactor from the top. Typical degradation times of organic wastewater compounds (dyes, ${ }^{5,6}$ pharmaceutics, ${ }^{7}$ and herbicides ${ }^{8,9}$ ) range from 60 to $180 \mathrm{~min}$. However, photocatalytic slurry reactors are very difficult to standardize according to their operational procedures, mostly due to the previously mentioned light penetration and distribution differences, making the relative comparison between the experiments performed in different reactors difficult. Furthermore, most of these reactors only allow the study of one reactive parameter (such as organic molecules or photocatalyst concentrations) at a time, ${ }^{1,4}$ and batch reactors usually consume relatively high amounts of the test materials (photocatalysts, organic contaminant, and oxidizing agents).

Optimization of the photocatalytic reactive conditions often needs to be performed when considering any new emerging organic contaminant to find the optimal mineralization conditions. Combinatorial chemistry and high throughput screening are two powerful concepts that enable rapid selection of the optimum reaction parameters. ${ }^{10}$ While mostly applied in conventional catalyst evaluation, some high throughput experiments recently have also been applied to photocatalyst evaluation. ${ }^{11-13}$ Specifically, Maier and co-workers ${ }^{11}$ established a high throughput method based on HPLC to evaluate several photocatalysts for 4-chlorophenol oxidative conversion. Xiao et al. ${ }^{12}$ developed fluorescent photoimaging methodology for the same purpose with both publications using slurry systems. It quickly becomes apparent that there is tremendous potential in developing uniform, inexpensive high throughput photocatalyst screening methods to maximize organic pollutant degradation efficiency.

In this work, we report a new high throughput screening method based on the use of 96-well plates for photocatalyst efficiency assessment, while also utilizing UV-vis spectrometry to track the degradation process of any light absorbing model organic wastewater compounds. The 96-well microplate base is widely used in many fields of sample preparation and analysis, such as drug efficiency screening in pharmacology, ${ }^{14}$ enzymatic studies in biochemistry, ${ }^{15}$ and high content biological cell bioassays. ${ }^{16}$ Utilizing these well plates allows reduction of the reagent and catalyst amount, easier handling, and higher sampling throughput. We validated our proposed method by

Received: April 18, 2014

Accepted: July 1, 2014

Published: July 1, 2014 


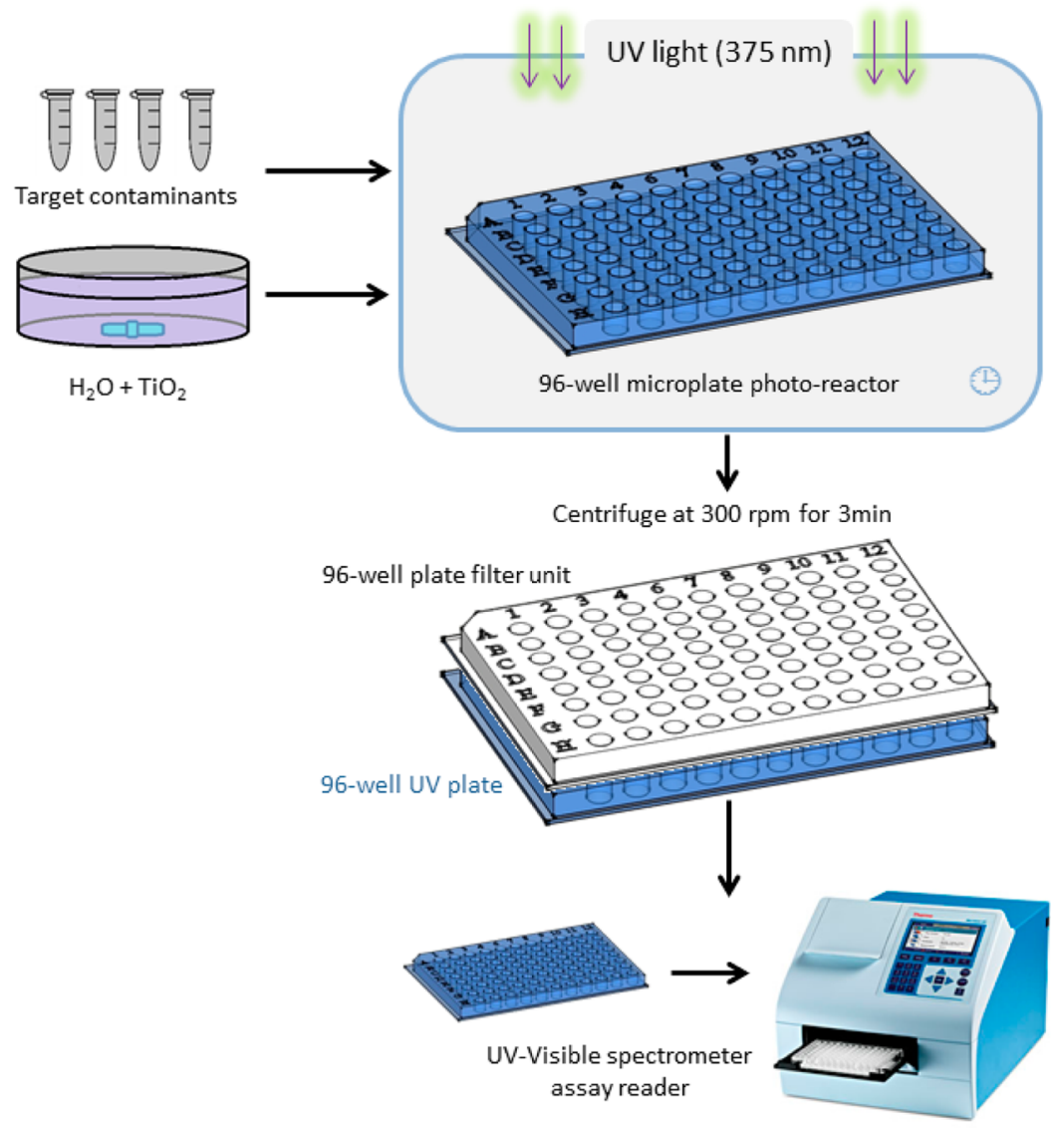

Figure 1. Scheme of the 96-well microplate based experimental protocol.

performing in situ photocatalytic degradation tests using a model organic wastewater compound, methyl orange (MO), with a specific focus on a few crucial reaction parameters, such as photocatalyst chemical composition, its concentration in the slurry, and the presence of salts (ionic species). The results of this method are compared with those reported in the literature in order to validate the proposed analytical system.

\section{EXPERIMENTAL SECTION}

Microplate Photoreactor Setup. The experimental setup of the high throughput photocatalytic screening experiment is shown in Figure 1 with the corresponding reactor positioning shown in Figure 2. Selected photocatalyst slurry compositions were prepared and transferred in equal volumes into the 96well microplate. A model organic pollutant was added, and each photodegradation experiment took place in an independent microwell (well diameter of $6.4 \mathrm{~mm}$ and depth of $11.2 \mathrm{~mm}$ ), situated within the microplate. The working volume was 200 $\mu \mathrm{L}$. A multitubular light source $\left(3.21 \mathrm{~mW} / \mathrm{cm}^{2}\right)$ with the light wavelength ranging from 360 to $380 \mathrm{~nm}$ was positioned $50 \mathrm{~mm}$ above the microplates. After each photocatalytic experiment, the resulting aqueous suspension containing the photocatalyst and the organic contaminant was transferred by a multimicropipet into a 96-well filter microplate (Corning, hydrophilic $0.2 \mu \mathrm{m}$ PVDF membrane). In order to separate the solid photocatalyst, the aqueous suspensions in the 96 well filter microplate were centrifuged into a third, 96-well UV transparent base plate (Corning), at $300 \mathrm{rpm}$ for $3 \mathrm{~min}$ (Figure 1). The extent of the organic molecule degradation was monitored using the disappearance of its corresponding absorbance

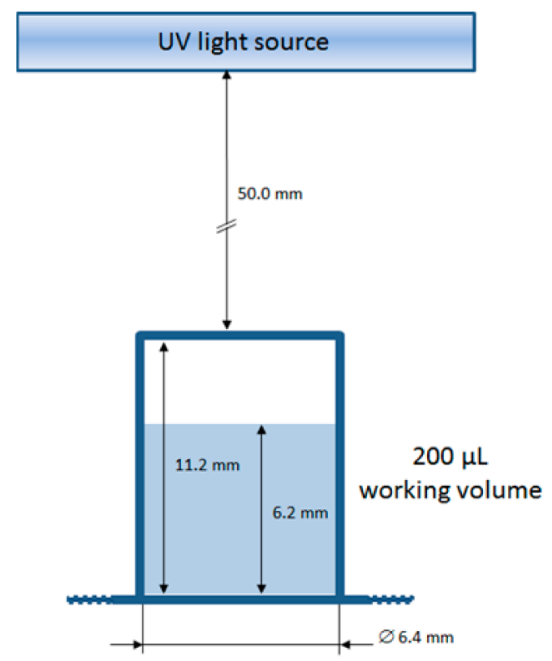

Figure 2. Microwell photoreactor dimensions. These dimensions were also used for MO concentration determination by UV-vis spectroscopy.

spectrum in a microplate spectrophotometer (Multiskan GO, Thermo Scientific) using the maximum value of the absorption band. MO was chosen as a model organic molecule to validate the method. The UV-vis spectra of MO in distilled water revealed two absorption bands at 270 and $465 \mathrm{~nm}$, with the latter used for quantification. No significant change in absorbance of $\mathrm{MO}$ was observed by dark adsorption on the catalyst surface or by illumination in the absence of catalyst material, in agreement with the literature. ${ }^{6}$ Photodegradation 
A

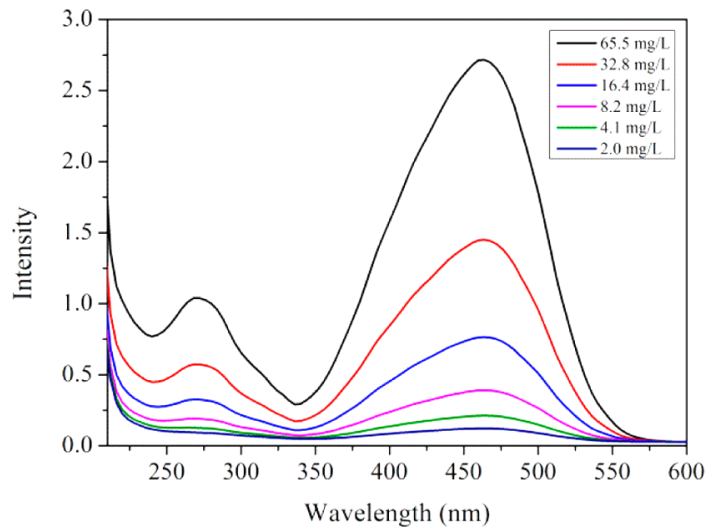

B

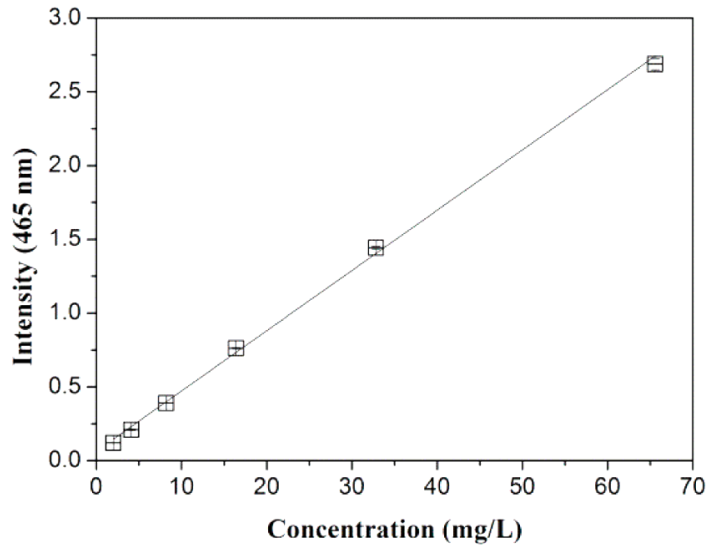

Figure 3. Evaluation of method accuracy and sensitivity of UV-vis analysis of MO. (A) UV-vis spectra at various MO concentrations. (B) Linear regression of data obtained in A with $R^{2}=0.99$.

measurements were performed in triplicate to determine the reproducibility values.

The 96-well microplate photoreactor allows for performance evaluation at many different conditions. In this study we demonstrate two cases of application:

- In the first case, the numbers on the top of the plate (columns 1-12) are filled with three different photocatalysts $\mathrm{ZnO}$, Hombikat $\mathrm{TiO}_{2}$ (Sachtleben), or P25 (Evonik) at four different catalyst concentrations $(0.1,0.25,0.5$, and $1.0 \mathrm{~g} / \mathrm{L}$ respectively), while the letters (A-E) represent different reaction times. The entire volume of each row $(200 \mu \mathrm{L})$ was transferred after a certain reaction time (wells A1 to A12) to the 96-well filter microplate. Rows $\mathrm{A}$ to $\mathrm{H}$ represent reaction times of $0,1,2.5,5,7.5,10,15$, and $30 \mathrm{~min}$, respectively. All experiments were performed at a natural $\mathrm{pH}$ of 6.1 .

- In the second example, the numbers correspond to different catalyst or $\mathrm{MO}$ concentrations and the letters to different salts. In this case, each plate corresponds to a single reaction time. Two plates were prepared, representing reaction times of 2.5 and $5 \mathrm{~min}$, respectively. The parameters studied were two $\mathrm{MO}$ concentrations of 5 and $10 \mathrm{mg} / \mathrm{L}$ and two P25 $\mathrm{TiO}_{2}$ catalyst concentrations, i.e., $0.25 \mathrm{~g} / \mathrm{L}$ and $0.5 \mathrm{~g} / \mathrm{L}$. The molar ratios between the MO concentration and the salts were, respectively, 1:1, 1:2, and 1:4. Columns $A$ to $H$ represent the salts according to the following order: sodium chloride, sodium phosphate dibasic, sodium carbonate, hydrochloric acid, potassium bromide, potassium nitrate, and potassium sulfate. All experiments were performed at natural $\mathrm{pH}, \mathrm{pH}$ 6.1; however the addition of $\mathrm{HCl}$ changed the $\mathrm{pH}$ to 3.0, and consequently the UV/vis absorption maximum of $\mathrm{MO}$ shifted to $508 \mathrm{~nm}$, from which maximum the concentration was derived in this particular experiment. ${ }^{6}$

All chemicals including methyl orange (MO), sodium chloride, sodium phosphate dibasic, sodium carbonate, hydrochloric acid, potassium bromide, potassium nitrate, and potassium sulfate were obtained from Aldrich and used without further purification.

\section{RESULTS AND DISCUSSION}

Methyl orange (MO) was selected to validate the microplate photoreactor system via photocatalytic degradation studies with a starting concentration of $10 \mathrm{mg} / \mathrm{L}$. MO is an organic dye that is commonly used as an organic model compound in wastewater photocatalytic degradation studies. ${ }^{6,17}$ Initially, to evaluate both the accuracy and the sensitivity of the microplate method described here, several aqueous $\mathrm{MO}$ solutions were prepared $(2.0,4.1,8.2,16.4,32.8$, and $65.5 \mathrm{mg} / \mathrm{L})$. UV-vis spectra of MO have two absorption band maxima situated at 270 and $465 \mathrm{~nm}$, as shown in Figure 3A. The band at $465 \mathrm{~nm}$ was used for quantification. Linear regression analysis was used to determine the linearity of this quantification method, its sensitivity, and the detection limit of the UV-vis spectrometer for the microwell based experiments, as shown in Figure 3B. The calibration sensitivity found was to be 0.04 ; the analytical sensitivities at MO concentrations of 65.5 and $2 \mathrm{mg} / \mathrm{L}$ were 1.02 and 19.05, respectively, whereas the limit of detection (LOD) was $0.15 \mathrm{mg} / \mathrm{L} \mathrm{MO}$. It can be seen that the linearity of the measurements remains constant up to at least $\sim 70 \mathrm{mg} / \mathrm{L}$ of $\mathrm{MO}$, a middle value of the concentration range that is typically found in industrial textile wastewater streams ${ }^{18}$ and used in laboratory scale photocatalytic degradation experiments. ${ }^{9}$

$\mathrm{TiO}_{2}$-based photocatalysts (P25 and Hombikat) and $\mathrm{ZnO}$ were tested for activity because of the stability of $\mathrm{TiO}_{2}$ in an aqueous environment and the known photocatalytic efficiency of $\mathrm{ZnO}^{19}$ The photocatalyst concentration used ranged between 0.1 and $1 \mathrm{~g} / \mathrm{L}$, which is typical for slurry reactors. ${ }^{20}$ A photocatalytic degradation efficiency of $10 \mathrm{mg} / \mathrm{L} \mathrm{MO}$ in the presence of $0.25 \mathrm{~g} / \mathrm{L}$ of various photocatalysts under top illumination of $375 \mathrm{~nm}$ light is shown in Figure 4. The data are the averages of three independent measurements, and error bars represent the standard deviation (STDEV) of those measurements. It can be seen that the STDEV obtained at each time point was very small at $\sim 1 \%$.

Figure 4 shows that most of the $\mathrm{MO}$ in aqueous solution, $\sim 93 \%$, was degraded after $15 \mathrm{~min}$ when using $\mathrm{ZnO}$, while degradation efficiencies achieved were $\sim 89 \%$ and $\sim 52 \%$ for $\mathrm{TiO}_{2} \mathrm{P} 25$ and $\mathrm{TiO}_{2}$ Hombikat, respectively. These results are consistent with those reported in the literature, where $\mathrm{ZnO}$ exhibits higher photocatalytic activity than $\mathrm{TiO}_{2} \mathrm{P} 25,{ }^{21,22}$ with the latter exhibiting greater activity than $\mathrm{TiO}_{2}$ Hombikat. ${ }^{6}$

Data shown in Figure 4 were processed to obtain the observed photocatalytic degradation rate constants $\left(k, \min ^{-1}\right)$, of which the values are listed in Table 1 . These were obtained using data point linearization of the initial MO degradation slope via pseudo-first-order kinetics:

$$
-\ln \left(\frac{C}{C_{0}}\right) \text { vs time }
$$




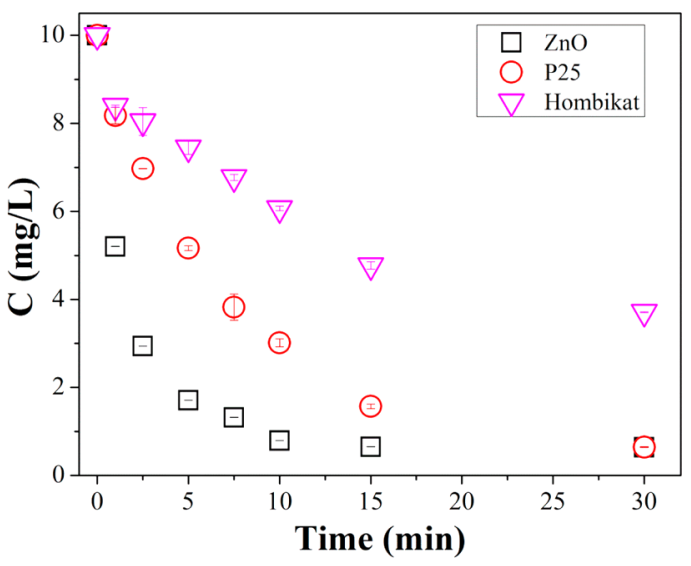

Figure 4. Photocatalytic decomposition of $10 \mathrm{mg} / \mathrm{L} \mathrm{MO}$ at $375 \mathrm{~nm}$ irradiation and $0.25 \mathrm{~g} / \mathrm{L}$ photocatalyst loading. Photocatalysts used were $\mathrm{TiO}_{2} \mathrm{P} 25, \mathrm{TiO}_{2}$ Hombikat, and $\mathrm{ZnO}$. The error bars are the calculated standard deviations of three independent experiments.

Table 1. Decomposition Rate Constants of MO Degradation in the Presence of Different Photocatalysts ${ }^{a}$

\begin{tabular}{lcc}
$\begin{array}{c}\text { catalyst } \\
(0.25 \mathrm{~g} / \mathrm{L})\end{array}$ & $\begin{array}{c}\text { pseudo-first order observed rate constant } \\
\left(\mathrm{min}^{-1}\right)\end{array}$ & $R^{2}$ \\
$\mathrm{ZnO}$ & 0.23 & 0.931 \\
$\mathrm{TiO}_{2} \mathrm{P} 25$ & 0.12 & 0.994 \\
$\mathrm{TiO}_{2}$ Hombikat & 0.04 & 0.933 \\
${ }^{a} R^{2}$ provided for the linear data fit according to eq 1. & \\
\hline
\end{tabular}

Table 1 shows that the highest observed rate constant was obtained for $\mathrm{ZnO}\left(0.23 \mathrm{~min}^{-1}\right)$. However, it is known that photocorrosion of $\mathrm{ZnO}$ in aqueous solutions leads to the formation of $\mathrm{ZnOH}^{+}, \mathrm{Zn}(\mathrm{OH})_{2}, \mathrm{Zn}(\mathrm{OH})_{3}{ }^{-}$, and other products that are not as active as photocatalysts. ${ }^{23,24}$ Thus, further experiments were performed using $\mathrm{TiO}_{2} \quad \mathrm{P} 25$ as photocatalyst material.

Another parameter studied was catalyst concentration, varying in the slurry ranging from 0.1 to $1 \mathrm{~g} / \mathrm{L}$ in the presence of an initial MO concentration of $10 \mathrm{mg} / \mathrm{L}$. The data obtained are shown in Figure 5.

Figure 5 shows that the degradation of $\mathrm{MO}$ increases as a function of increasing concentration of $\mathrm{TiO}_{2} \mathrm{P} 25$. Additionally,

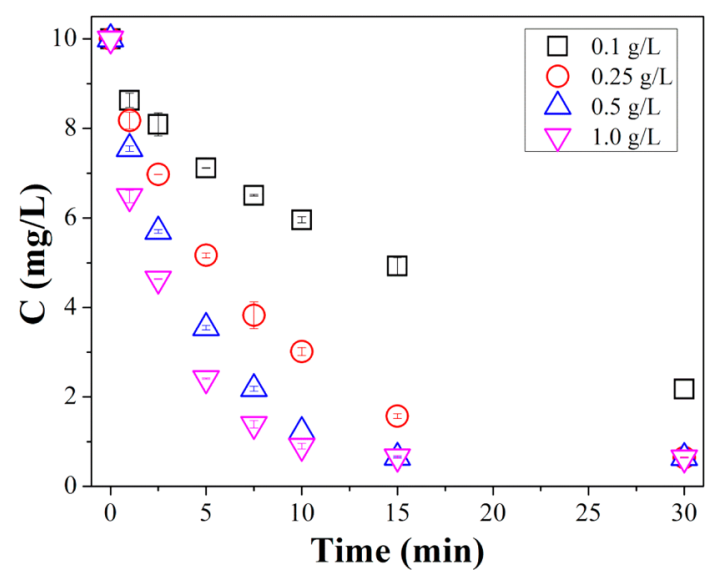

Figure 5. Photocatalytic decomposition of $10 \mathrm{mg} / \mathrm{L} \mathrm{MO}$ at $375 \mathrm{~nm}$ irradiation and using various concentrations of $\mathrm{TiO}_{2} \mathrm{P} 25(0.1-1 \mathrm{~g} / \mathrm{L})$. The error bars represent the deviation between the three independent experiments. an excellent reproducibility was obtained with almost negligible STDEV calculated. Observed initial rate constants $\left(k, \min ^{-1}\right)$ were calculated using a linearization of the data points shown in Figure 5 and are listed in Table 2.

Table 2. Observed initial rate constants of MO degradation in the presence of various loadings of $\mathrm{TiO}_{2} \mathrm{P}_{2} 5^{a}$

\begin{tabular}{|c|c|c|}
\hline $\begin{array}{c}\mathrm{TiO}_{2} \mathrm{P} 25 \text { concentration } \\
(\mathrm{g} / \mathrm{L})\end{array}$ & $\begin{array}{l}\text { pseudo-first order observed rate constant } \\
\qquad\left(\mathrm{min}^{-1}\right)\end{array}$ & $R^{2}$ \\
\hline 0.1 & 0.048 & 0.956 \\
\hline 0.25 & 0.124 & 0.994 \\
\hline 0.5 & 0.198 & 0.997 \\
\hline 1.0 & 0.256 & 0.992 \\
\hline
\end{tabular}

${ }^{a} R^{2}$ provided is that for the linear data fit according to eq 1 .

Table 2 shows that the observed initial decomposition rate constant, $k\left(\mathrm{~min}^{-1}\right)$, increases with the $\mathrm{TiO}_{2} \mathrm{P} 25$ concentration in the slurry. The trend is shown in Figure 6.

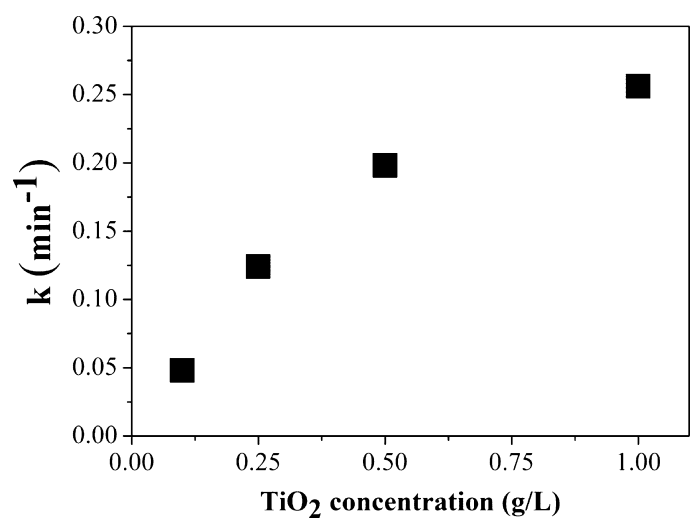

Figure 6. Effect of catalyst concentration on pseudo-first-order rate constant of $\mathrm{TiO}_{2} \mathrm{P} 25$ in decomposing MO.

The observed trend is in agreement with the findings reported in the literature. ${ }^{6}$ Catalyst concentration is one of the most important parameters of slurry reactors and can be correlated with its availability per unit volume for photocatalytic reaction. However, after increasing up to a certain amount, it becomes impossible to achieve a better decomposition rate due to the limited light penetration through the vessel, and deviation from linearity in the curve of Figure 6 is apparent. ${ }^{25}$ $\mathrm{TiO}_{2}$ concentrations of $1-2 \mathrm{~g} / \mathrm{L}$ have already have been shown to significantly scatter incident light and thus can be considered as a maximum usable value. ${ }^{25}$ Our data shown in Figure 5 for 0.5 and $1.0 \mathrm{~g} / \mathrm{L}$ agree with this observation, suggesting that in microplate photoreactors of small volumes, the photocatalyst is utilized efficiently within the same concentration range, as typically observed in batch reactors. Additionally, photocatalytic slurry reactors are commonly supported by agitation to ensure a uniform distribution of the photocatalyst. However, in the microplate system proposed in this paper, agitation could not be applied. As a result, there is a progressive deposition of the photocatalyst at the bottom of the microwell. This is expected to be compensated by relatively short diffusion paths of the reactant molecules within the small reactor dimensions. This will allow the molecules to reach the photocatalyst surface, at these microliter volumes, within the duration of the experiment ( $\sim 15 \mathrm{~min})$. Assuming an MO diffusion coefficient, $D$, of $1 \times$ $10^{-5} \mathrm{~cm}^{2} / \mathrm{s}$, ${ }^{26}$ the diffusion length $(2 \sqrt{ }(D t)$, where $t$ is the 
Table 3. Comparison of Observed Initial Rate Constants $(k)$ of MO Degradation, between the 96 Well Microreactor with Others

\begin{tabular}{|c|c|c|c|c|c|c|c|c|}
\hline $\begin{array}{l}{[\mathrm{MO}]} \\
(\mathrm{mg} / \mathrm{L})\end{array}$ & $\begin{array}{c}{[\mathrm{P} 25 \mathrm{TiO} 2]} \\
(\mathrm{g} / \mathrm{L})\end{array}$ & type of reactor & $\begin{array}{l}\text { reactor volume } \\
\quad(\mathrm{mL})\end{array}$ & light source & $\begin{array}{c}k \\
\left(\min ^{-1}\right)\end{array}$ & $\begin{array}{l}96 \text { well microreactor } k \\
\left(\mathrm{~min}^{-1}\right)\end{array}$ & $\begin{array}{c}k \text { (slurry reactor) } / k \text { (well } \\
\text { plate) }\end{array}$ & ref \\
\hline 20 & 0.08 & $\begin{array}{l}\text { slurry/ } \\
\text { suspension }\end{array}$ & 150 & $\begin{array}{l}\text { black light tubes } \\
\quad 4 \mathrm{~W}\end{array}$ & 0.0244 & 0.0480 & 0.51 & 28 \\
\hline 10 & 0.5 & $\begin{array}{l}\text { slurry/ } \\
\text { suspension }\end{array}$ & 7.5 & $\underset{\mathrm{cm}^{-2}}{\mathrm{UV} \text { lamp } 50 \mathrm{~mW}}$ & 0.5200 & 0.1980 & 2.63 & 29 \\
\hline 10 & 0.5 & $\begin{array}{l}\text { slurry/ } \\
\text { suspension }\end{array}$ & 1100 & UV lamp $11 \mathrm{~W}$ & 0.0076 & 0.1980 & 0.04 & 30 \\
\hline 10 & 1.0 & $\begin{array}{l}\text { slurry/ } \\
\text { suspension }\end{array}$ & 1100 & UV lamp $11 \mathrm{~W}$ & 0.0097 & 0.2560 & 0.04 & 30 \\
\hline 20 & 1.0 & $\begin{array}{l}\text { slurry/ } \\
\text { suspension }\end{array}$ & 50 & $\begin{array}{l}\text { black light tubes } \\
18 \mathrm{~W}\end{array}$ & 0.0110 & 0.2560 & 0.04 & 31 \\
\hline
\end{tabular}
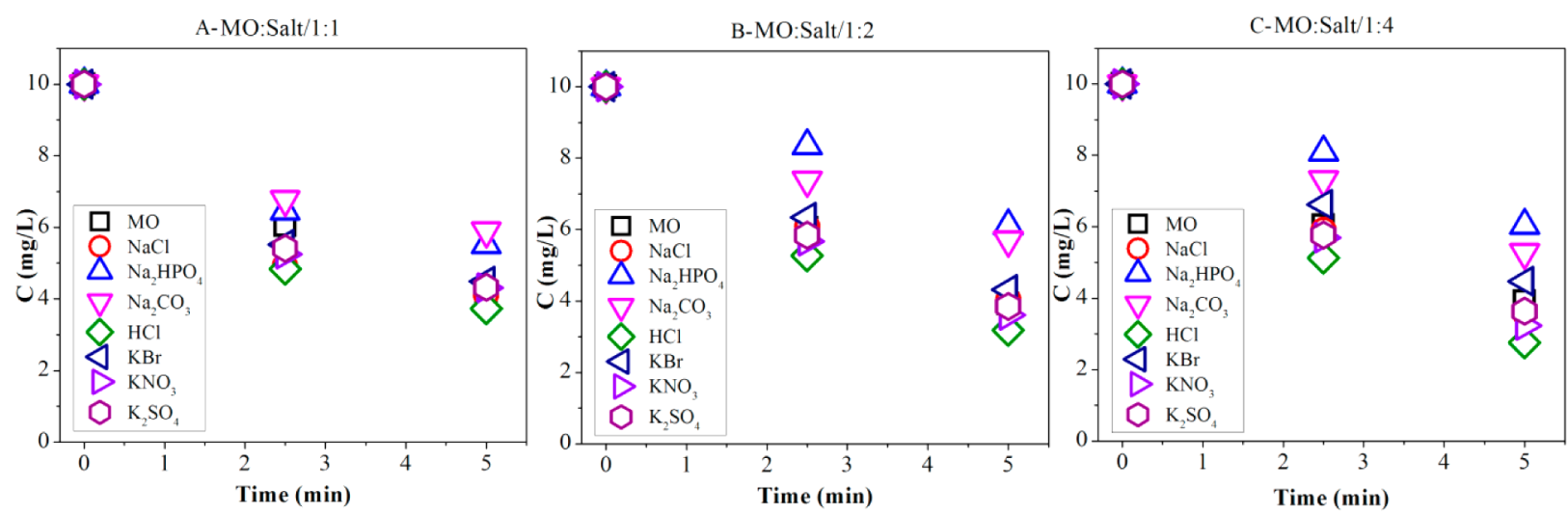

Figure 7. Photocatalytic degradation of $\mathrm{MO}(5 \mathrm{mg} / \mathrm{L})$ with $\mathrm{P} 25 \mathrm{TiO}_{2}(0.25 \mathrm{~g} / \mathrm{L})$ in the presence of various anions and cations. The molar ratio between $\mathrm{MO}$ and the salts were respectively 1:1(A), 1:2 (B), and 1:4 (C).

reaction time to degrade $\sim 90 \%$ of $\mathrm{MO}$, in seconds) was estimated to be $0.2 \mathrm{~cm}$, close to the vertical reactor dimensions. This means that even with a complete settling of the photocatalyst material, all of the MO molecules will have been interacting with the catalyst particles within the reaction time frame.

The comparison between the observed rate constant of the microplate photoreactor with other slurry reactors is difficult, since this depends on various experimental parameters, such as the reactor geometry, light source, and its position in the reactor, ${ }^{27}$ as well as the initial concentration of the model waste compound. Table 3 shows the observed rate constant values obtained from the 96-well microplate photoreactors in comparison with other studies.

Clearly, the rate constant value obtained in our study in the well plate is higher than those obtained in conventional laboratory slurry reactors of larger volume. One of the disadvantages of a typical slurry reactor equipped with top illumination is that the light intensity decreases with increasing reactor depth due to absorption/scattering by photocatalyst particles or even the solution itself. Hence, only catalyst particles in the upper volume of the reactor contribute efficiently to the photocatalytic process. $^{32}$ Our 96-well microplate photorector circumvents the problem due to the high top surface area-to-volume ratio $\left(A / V, \mathrm{~cm}^{-1}\right)$. Specifically, $A / V$ of a single well in the current system is $1.61 \mathrm{~cm}^{-1}$, while that reported for typical batch reactors is at least an order of magnitude smaller, as shown in Table 3 . High $A / V$ values in our microwell setup enable an efficient utilization of the photocatalyst volume while decreasing the total required amounts of both catalyst and solution. The observed initial rate constant $(k)$ determined in the well plate seems to correspond to the value obtained in a reactor configuration in which the reactor volume is only $7.5 \mathrm{~mL}$ (Table 3). In this case, the observed initial rate constant $(k)$ value is in the same order of magnitude than the one obtained in the 96-well microplate photoreactor. This observation confirms that the observed initial rate constant $(k)$ values are closely related to reactor geometry.

As a second example to demonstrate the potential of our method, we have performed experiments with different salt concentrations added to the MO/catalyst mixture. Figure 7, summarizes the results.

As is reported in the literature, the presence of ionic species can accelerate or retard the observed initial reaction rate. ${ }^{33,34}$ The ionic species chosen represent some of the most common species present in wastewater. From the ionic species tested, only phosphate and carbonate anions show a significantly negative effect on the reaction rate constant of MO degradation (Figure 7). These results are generally in agreement with what is reported in the literature for dyes. ${ }^{33,34}$ Further, addition of $\mathrm{HCl}$ appears to promote the rate at which $\mathrm{MO}$ is degraded. The addition of $\mathrm{HCl}$ has been reported to negatively affect the rate of degradation of various substrates, ${ }^{33,34}$ but the literature does not contain information on the effect of $\mathrm{HCl}$ on $\mathrm{MO}$ decomposition rates. The positive effect found in our studies is most likely related to the decrease in $\mathrm{pH}$ induced by the addition of $\mathrm{HCl}$. Acidic conditions are known to favor the decomposition of MO. ${ }^{6}$ The photocatalytic degradation reaction of $\mathrm{MO}$ in the presence of the other salts did not show any appreciable effect in the observed reaction rate constant, again in agreement with the literature. ${ }^{33,34}$ 


\section{CONCLUSIONS}

In summary, we propose a method of high throughput photocatalyst screening that requires very short reaction times of up to $15 \mathrm{~min}$ to degrade dye compounds in the concentration range typical of those found in industrial organic wastewaters. This method is applicable to a wide concentration range of model organic contaminants, powder photocatalysts, and various combinations of these. Furthermore, this method minimizes the amount of the photocatalyst needed and the volume of the working solution from typical values of 50-1000 $\mathrm{mL}$ to only $200 \mu \mathrm{L}$. Finally, this method allows the efficient utilization of all the photocatalyst present within the reactor, thus providing a more realistic value of the intrinsic rate constant in photocatalytic applications. The validity of the method was also demonstrated in an evaluation of the effect of salt concentrations on the effective rate constant. In agreement with the literature, phosphate and carbonate anions were found to decrease the rate of decomposition of $\mathrm{MO}$, whereas acidic conditions favor the rate.

\section{ASSOCIATED CONTENT}

\section{S Supporting Information}

Characterization of the photocatalysts used (XRD and BET) is provided in Table S1 and Figure S1. This material is available free of charge via the Internet at http://pubs.acs.org.

\section{AUTHOR INFORMATION}

\section{Corresponding Authors}

*E-mail: G.Mul@utwente.nl.

*E-mail: J.Baltrusaitis@utwente.nl.

\section{Present Address}

${ }^{\S}$ Department of Chemical and Biomolecular Engineering, Lehigh University, B336 Iacocca Hall, 111 Research Drive, Bethlehem, PA 18015, United States. E-mail: job314@lehigh. edu

\section{Notes}

The authors declare no competing financial interest.

\section{ACKNOWLEDGMENTS}

This work was supported by NanoNextNL, a micro- and nanotechnology consortium of the Government of The Netherlands and 130 partners.

\section{REFERENCES}

(1) Atul, V. W.; Gaikwad, G. S.; Dhonde, M. G.; Khaty, N. T.; Thakare, S. R. Res. J. Chem. Environ. 2013, 17, 84-94.

(2) Chong, M. N.; Jin, B.; Chow, C. W. K.; Saint, C. Water Res. 2010, 44, 2997-3027.

(3) Mukherjee, P. S.; Ray, A. K. Chem. Eng. Technol. 1999, 22, 253260.

(4) Lazar, M. A.; Varghese, S.; Nair, S. S. Catalysts 2012, 2, 572-601.

(5) Houas, A.; Lachheb, H.; Ksibi, M.; Elaloui, E.; Guillard, C.;

Herrmann, J. M. Appl. Catal., B 2001, 31, 145-157.

(6) Guettai, N.; Amar, A. Desalination 2005, 185, 427-437.

(7) Choina, J.; Kosslick, H.; Fischer, C.; Flechsig, G. U.; Frunza, L.; Schulz, A. Appl. Catal., B 2013, 129, 589-598.

(8) Parra, S.; Stanca, S. E.; Guasaquillo, I.; Thampi, K. R. Appl. Catal., B 2004, 51, 107-116.

(9) Jiang, H.; Zhang, G.; Huang, T.; Chen, J.; Wang, Q.; Meng, Q. Chem. Eng. J. 2010, 156, 571-577.

(10) Stowe, K.; Ausfelder, F. Chem. Eng. Technol. 2013, 85, 919-925.

(11) Lettmann, C.; Hinrichs, H.; Maier, W. F. Angew. Chem., Int. Ed. 2001, 40, 3160-3164.
(12) Xiao, H. Y.; Dai, Q. X.; Li, W. S.; Au, C. T.; Zhou, X. P. J. Mol. Catal. A: Chem. 2006, 245, 17-25.

(13) Nakayama, A.; Suzuki, E.; Ohmori, T. Appl. Surf. Sci. 2002, 189, 260-264.

(14) Chiang, P. C.; Ran, Y. Q.; Chou, K. J.; Cui, Y.; Sambrone, A.; Chan, C. N.; Hart, R. AAPS PharmSciTech 2012, 13, 713-722.

(15) Barig, S.; Schiemann, M.; Mirsky, V. M.; Stahmann, K. P. Anal. Bioanal. Chem. 2013, 405 (26), 8539-8547.

(16) Behnisch, P. A.; Hosoe, K.; Brouwer, A.; Sakai, S. Toxicol. Sci. 2002, 69, 125-130.

(17) Al-Quadawi, S.; Salman, S. R. J. Photochem. Photobiol., A 2002, $148,161-168$.

(18) Manu, B.; Chaudhari, S. Bioresour. Technol. 2002, 82, 225-231.

(19) Chan, S. H. S.; Wu, T. Y.; Juan, J. C.; Teh, C. Y. J. Chem. Technol. Biotechnol. 2011, 86, 1130-1158.

(20) Ahmed, S.; Rasul, M. G.; Martens, W. N.; Brown, R.; Hashib, M. A. Water Air Soil Poll. 2011, 215, 3-29.

(21) Kansal, S. K.; Singh, M.; Sud, D. J. Hazard. Mater. 2007, 141, 581-590.

(22) Wang, C.; Xu, B.-Q.; Wang, X.; Zhao, J. J. Solid State Chem. 2005, 178, 3500-3506.

(23) Sakthivel, S.; Neppolian, B.; Shankar, M. V.; Arabindoo, B.; Palanichamy, M.; Murugesan, V. Sol. Energy Mater. Sol. Cells 2003, 77, 65-82.

(24) Neppolian, B.; Choi, H. C.; Sakthivel, S.; Arabindoo, B.; Murugesan, V. J. J. Hazard. Mater. 2002, 89, 303-317.

(25) Konstantinou, I. K.; Sakkas, V. A.; Albanis, T. A. Appl. Catal., B 2001, 34, 227-239.

(26) Leaist, D. G. J. Colloid Interface Sci. 1988, 125, 327-332.

(27) Yue, P. L. In Photoelectrochemistry, Photocatalysis, and Photoreactors: Fundamental and Developments; Schiavello, M., Ed.; Springer: New York, 1985.

(28) Li, W. J.; Li, D. Z.; Wang, J. X.; Shao, Y.; You, J. M.; Teng, F. J. Mol. Catal. A: Chem. 2013, 380, 10-17.

(29) Morales-Torres, S.; Pastrana-Martinez, L. M.; Figueiredo, J. L.; Faria, J. L.; Silva, A. M. T. Appl. Surf. Sci. 2013, 275, 361-368.

(30) Cheng, Z. L.; Quan, X. J.; Xiong, Y. Q.; Yang, L.; Huang, Y. M. Ultrason. Sonochem. 2012, 19, 1027-1032.

(31) Hamdy, M. S.; Saputera, W. H.; Groenen, E. J.; Mul, G. J. Catal. 2014, 310, 75-83.

(32) Carneiro, J. T.; Berger, R.; Moulijn, J. A.; Mul, G. Catal. Today 2009, 147, S324-S329.

(33) Konstantinou, I. K.; Albanis, T. A. Appl. Catal., B 2004, 49, 1 14.

(34) Epling, G. A.; Lin, C. Chemosphere 2002, 46, 937-944. 